\title{
Induktivisme-Empirisisme Francis Bacon dan Relevansinya Bagi Ilmu-Ilmu Keagamaan
}

\section{Yeni Setianingsih}

UIN Sunan Kalijaga Yogyakarta

yenisetianingsih@gmail.com

\begin{abstract}
Based on observations made by the senses on events that occur around humans, in the treasury of philosophy there are two ways to draw a conclusion, namely deductive and inductive. Francis Bacon is a philosopher who is known by the principle of thinking that is Induktivism-Empiricism. This method can also be applied in the study of religious knowledge that is related to the establishment of law or known as figh. This article will explore how Bacon's Inductivism-Empiricalism thought and its relevance to the science of religion. This article uses a descriptive analysis method. Bacon's thinking is that conclusions are drawn from something specific and then drawn to the general. With an objective assessment, this method is able to solve religious problems that are now popping up a lot.
\end{abstract}

Keywords: Induktivisme-Empirisisme, Francis Bacon, Ilmu-ilmu kegamaan.

Abstrak : Bertolak dari pengamatan yang dilakukan oleh indra terhadap peristiwa-peristiwa yang terjadi disekitar manusia, dalam khasanah filsafat terdapat dua cara dalam mengambil kesimpulan, yakni model deduktif dan induktif. Francis Bacon adalah seorang filusuf yang dikenal dengan prinsip berpikirnya yang bersifat Induktivisme-Empirisisme. Metode ini juga dapat diterapkan dalam kajian ilmu keagamaan yakni terkait dengan penetapan hukum atau dikenal dengan istilah figh. Artikel ini 
akan mengupas bagaimana pemikiran InduktivismeEmpirisisme Bacon dan relevansinya terkait ilmu kegamaan. Artikel ini menggunakan metode deskriptif analisis. Pemikiran Bacon yakni pengambilan kesimpulan bertolak dari sesuatu yang khusus untuk kemudian ditarik kepada yang umum. Dengan penilaian yang objektif, metode ini mampu memecahkan masalah-masalah keagamaan yang sekarang banyak bermunculan.

Kata Kunci: Induktivisme-Empirisisme, Francis Bacon, Ilmu-ilmu kegamaan.

\section{A. Pendahuluan}

Filsafat seringkali bernuansa konspiratif. Ia jatuh dalam beberapa kasus, karena dianggap memberontak dari tatanan yang telah mapan. Padahal sebenarnya, justru dengan berfilsafatlah semua akan terungkap, karena pada dasarnya alam beserta isinya ini tidak akan bermakna apaapa jika pikiran-pikiran jenius itu tidak bergerak. Untuk itu, dibutuhkanlah apa yang dinamakan dengan ilmu pengetahuan, dan salah seorang filsuf yang mempunyai perhatian besar akan hal itu adalah Francis Bacon. Menurutnya, tujuan ilmu adalah penguasaan manusia terhadap alam. Ilmu harus mempunyai kegunaan praktis dan menambah superioritas manusia terhadap alam semesta. Dengan ilmu, manusia akan dapat menundukkan alam. Karena itu, ungkapan plato "knowledge is power" menjadi semboyan bagi Bacon.

Selanjutnya Bacon mengatakan bahwa, ilmu pengetahuan dan ilmuwan sampai dengan zamannya terlalu berupaya untuk mengontrol dan memanipulasi alam menurut kehendaknya. Alam tidak didekati sebagaimana adanya melainkan menurut kehendak manusia. Alam lalu dipaksa untuk cocok dengan pengandaian dan cara pandang manusia. Alam juga tidak dibiarkan untuk memperlihatkan dirinya sebagaimana adanya, tetapi selalu ditangkap dalam bingkai sudut pandang manusia. Sehingga, dapat dikatakan bahwa manusia itu terlalu berupaya memaksakan keteraturan pada alam, padahal mungkin saja tidak ada keteraturan tersebut. Ia juga menganggap bahwa ilmu pengetahuan lama tidak mampu memberi kemajuan dan tidak mampu menghasilkan hal-hal baru yang bermanfaat bagi kehidupan. Atas dasar inilah Bacon menyusun metode barunya untuk mengkritik metode lama yang selama 
ini digunakan oleh para pendahulunya, yaitu metode deduksi yang telah dikembangkan oleh Aristoteles. Disamping itu juga ia mengkritik kaum rasionalis, yang lebih mengutamakan akal budi dan mengesampingkan peran indera dalam menemukan kebenaran. Menurut Bacon para rasionalis sudah memiliki kebenaran atau kesimpulan a priori tertentu dalam benaknya, baru berusaha untuk memaksakan objek agar cocok dengan apa yang sudah mereka pikirkan. ${ }^{1}$

Atas gagasannya inilah Bacon dapat dikatakan sebagai peletak dasar lahirnya faham empirisme, yang untuk kali pertama menyatakan pengalaman sebagai sumber kebenaran yang paling dipercaya. ${ }^{2}$ Paham empirisme ini kemudian diikuti dan dikembangkan oleh Thomas Hobbes (1588-1679), John Locke (1632-1704), George Barkeley (1685-1753), dan mencapai puncaknya pada David Hume (1711-1776). Lebih jauh lagi John Locke mengatakan seluruh sisa pengetahuan kita diperoleh dengan jalan menggunakan serta membandingkan ide-ide yang diperoleh dari penginderaan. John Locke memandang akal sebagai sejenis tempat penampungan, yang secara pasif menerima hasil-hasil penginderaan tersebut. ${ }^{3}$ Dari sinilah lahir apa yang dia katakan sebagai metode induksi modern yang mensistimatisasikan secara logis prosedur ilmiah. Dikatakan induksi modern karena memang Bacon bukanlah orang pertama yang meluncurkan metode induksi, tetapi sebelunya telah ada ilmuan yang juga mengembangkan metode tersebut yang oleh Bacon dinamakan dengan induksi tradisional. Sedangkan gagasannya ini lebih dikenal dengan nama "induksi Baconian." Dengan metode barunya ini dia ingin menjadikan manusia mampu menguasai kekuatan-kekuatan alam dengan perantaraan penemuan-penemuan ilmiah. Mengenai metodenya ini Bacon menuangkannya dalam bukunya yang berjudul Novum Organum yang diterbitkan pada tahun $1620 .^{4}$

${ }^{1}$ A. Sonny Keraf, Mikhael Dua, Ilmu Pengetahuan; Sebuah Tinjauan Filosofis (Yogyakarta: Kanisius, 2001), h. 100.

${ }^{2}$ Sembodo Ardi Widodo, David Hume dan Metafisika Empirik dalam Zubaedi, dkk, Filsafat Barat; Dari Logika Baru Rene Descartes Hingga Revolusi Sains ala Thomas Kuhn (Yogyakarta: ar-Ruzz Media 2007), h. 31.

${ }^{3}$ Louis O. Kattsoff, Pengantar Filsafat, terj. Soejono Soemargono, (Yogyakarta: Tiara Wacana, 2004), cet. IX, h. 133.

${ }^{4}$ Ali Maksum, Pengantar Filsafat (Yogyakarta: ar-Ruzz Media, 2011), cet. IV, h. 199-120. 
Dalam penggunaan metodenya Bacon sangat menekankan pada induksi-empiristik dan menjadikan metode ini sebagai satu-satunya metode ilmiah yang sah dalam pengembangan ilmu. Dia menulis Novum Organum (Metode baru) sebagai tandingan terhadap logika Aristoteles yang terdapat dalam karya Organom. Pemikirannya tentang ilmu pengetahuan sangat terkenal pragmatis fungsional. Menurutnya ilmu hanya bermakna jika dapat diterapkan secara praktis. Menarik kiranya untuk mengetahui pembahasan induktivisme Bacon yang dalam perkembangan periode berikutnya banyak diikuti oleh ilmuan Barat lainnya seperti Boyle, Newton, John Lock dan tokoh empirisme lainnya.

Pemikiran Bacon memang telah ada yang meneliti diantaranya Irfan noor ${ }^{5}$, Emanuel Prasetyono. ${ }^{6}$ Berbeda dengan pembahasan yang sebelumnya, dalam pembahasan ini, penulis akan mencoba mendeskripsikan pertentangan induktivisme Bacon dengan metode berpikir deduktif Aristoteles yang sebelum masanya menjadi pegangan teori berpikir para ilmuan. Setelah itu penulis akan mencoba menarik relevansinya bagi ilmu-ilmu keagamaan. Sebab, tidak dapat dipungkiri bahwa cara metode induksi ini sebenarnya telah banyak digunakan oleh ilmuan-ilmuan Muslim dalam menetapkan hukum Islam. Penelitian ini menggunakan metode deskriptif analisis.

\section{B. Kehidupan Francis Bacon dan Karya-karyanya}

Francis Bacon adalah anak dari Lord Nicholas Bacon salah seorang pejabat tinggi Kerajaan Inggris di zaman kekuasaan Ratu Elizabeth I. Bacon lahir di York House London, Inggris, pada 22 Januari 1561. Dia hidup di abad pertengahan dimana kebebasan ilmu pengetahuan diagungkan. Pada usia 12 tahun, dia telah bersekolah di Trinity College, Cambridge University. ${ }^{7}$ Disinilah dia mempelajari pemikiran Plato dan Aristoteles untuk kemudian dikembangkan menjadi sebuah pemikiran yang antipati terhadap filsafat Aristoteles. Tahun 1576, dia diangkat menjadi salah seorang staf kedutaan Inggris di Prancis.

\footnotetext{
${ }^{5}$ Irfan noor, Induksi Sebagai Metode Ilmiah (Kajian Tentang Filsafat
} Ilmu Francis Bacon) dalam jurnal Khazanah: Jurnal Studi Islam Dan Humaniora. Vol 8, No 1 (2010).

${ }^{6}$ Emanuel Prasetyono, Manusia, Ilmu Pengetahuan dan Kesadaran Diri dalam jurnal Orientasi Baru, Vol. 22, No. 2, Oktober 2013 1996), h. 113.

7 Jan Hendrik Rapar, Pengantar Filsafat (Yogyakarta: KANISIUS, 
Kemudian diusianya yang ke 23 tahun dia diangkat menjadi anggota parlemen. ${ }^{8}$

Pada tahun 1580, Bacon kembali ke London setelah mendapat kabar bahwa ayahnya meninggal dunia. Kemudian dia melanjutkan studi tentang hukum di Gray Inn, dan bekerja sebagai pengacara. Pada tahun 1586 dia diangkat sebagai penasihat negara. Setelah 11 tahun bekerja, Bacon dituduh oleh parlemen menerima suap dan akhirnya dimasukan ke penjara pada tahun 1598. Selama dalam tahanan, Bacon sangat aktif melakukan kajian intelektual dan eksperimen ilmiah. Bacon menghabiskan waktunya di penjara kurang lebih selama lima tahun. Hukuman ini diberikan oleh pemerintahan ratu Elizabeth I setelah mempertahankan prinsip yang bertentangan dengan pihak kerajaan. Selama di penjara dia juga dijauhkan dari kehidupan publik, namun akhirnya dia mendapatkan remisi dari pihak kerajaan setelah beberapa waktu lamanya.

Namun setelah Ratu Elizabeth tutup usia tahun 1603, dia diangkat menjadi penasihat Raja James I. Pada masa pemerintahan James I inilah, karir Bacon di kalangan pemerintahan maju pesat. Tahun 1607 dia menjadi konsultan umum bidang hukum dan tahun 1613 dia menjadi jaksa agung. Karirnya tidak selesai di tangga tersebut, tahun 1618 dia ditunjuk sebagai Ketua Majelis Tinggi, suatu kedudukan yang setingkat dengan hakim agung pada Mahkamah Agung di Amerika Serikat. Pada tahun itu juga dia memperoleh gelar "Baron" dan ditahun 1621 dinobatkan lagi jadi "Viscount St. Albans", satu gelar kebangsawanan diatas "Baron" tetapi di bawah "earl." Pada akhir usianya, Setelah menderita sakit yang cukup serius, tepatnya pada tanggal 9 April 1626, Bacon meninggal dunia di kota kelahirannya London, diantara karyanya yang sangat terkenal adalah The Advancement of Learning (1606), yang kemudian disadur kembali pada tahun 1623 dengan judul De Dignitate et Augmentis Scientarium (Tentang Perkembangan Luhur Ilmu-ilmu). The Advencement of Learning ini berisi informasi mengenai klasifikasi ilmu yang meliputi: (1) History (memory) yang merupakan bagian dari aktivitas mental manusia yang berkenaan dengan pendataan fakta-fakta partikular dan individual; (2) Poesy (imagination) yang berusaha mengimajinasikan

\footnotetext{
${ }^{8}$ Ibid, h.113.

${ }^{9}$ Jan Hendrik Rapar, Pengantar Filsafat, h. 113.
} 
pengetahuan dengan kekayaan data-data partikular yang dimiliki manusia; dan (3) Philosophy (reason), yaitu sejarah alam dan manusia menjadi data penting manusia untuk merefleksikan dunia alam dari dunia alam, bukan dari spekulasi apalagi imaginasi pikiran. Lima belas tahun kemudian tepatnya ditahun 1620 , dia menulis sebuah buku berjudul Novum Organum (Organum Baru). Karya ini menetapkan suatu metodologi baru dalam memahami alam secara eksperimental. ${ }^{10}$

\section{Pandangan Francis Bacon Terhadap Sistem Pengetahuan: Kritik Atas Metode Deduksi Aristoteles}

Inti dari logika Aristoteles yang kita kenal selama ini adalah silogisme. Silogisme ini merupakan suatu alat dan mekanisme penalaran untuk menarik konklusi yang benar berdasarkan premis-premis yang benar yang merupakan bentuk formal dari penalaran deduktif. Menurutnya, penalaran deduksif ini merupakan metode terbaik untuk memperoleh konklusi demi meraih pengetahuan dan kebenaran yang baru. Itulah sebabnya mengapa metode Aristoteles ini disebut metode "silogistis-deduktif." 11

Sebagai bentuk formal dari deduksi, silogisme terdiri dari tiga proposisi. Proposisi pertama dan kedua disebut premis, sedangkan proposisi kedua disebut konklusi yang ditarik dari proposisi pertama dengan dibantu proposisi kedua. Jadi silogisme mempunyai dua premis dan satu konklusi. Yang menjadi subjek konklusi disebut term minor, dan yang menjadi predikat konklusi disebut term mayor. Sedangkan term yang terdapat pada kedua proposisi disebut term tengah (terminus medius). Penalaran deduktif adalah suatu prosedur yang berpangkal pada suatu peristiwa umum, yang kebenarannya telah diketahui atau diyakini, dan berakhir pada suatu kesimpulan atau pengetahuan baru yang bersifat lebih khusus.

Contoh: Semua manusia pasti mati

Aristoteles adalah manusia

Jadi, Aristoteles pasti mati

${ }^{10}$ C. Verhaak S.J, R. Haryonono Imam, Filsafat Ilmu Pengetahuan (Jakarta: Gramedia Pustaka Utama, 1991), h.138.

${ }^{11}$ Jan Hendrik Rapar, Pengantar Filsafat, h. 105. 
Pola kerja yang ditempuh dalam penalaran silogistis-deduktif adalah dengan menetapkan suatu kebenaran universal terlebih dahulu untuk kemudian menjabarkannya pada hal-hal yang khusus. ${ }^{12}$ Dalam hal inilah Bacon mengkritik tajam terhadap cara dari prosedur tersebut diambil. Dalam teori induktifnya, Bacon mempermasalahkan tiga indikasi: pertama, Aristoteles dan pengikutnya mempraktekan koleksi data yang tidak kritis. Dalam hubungan ini Bacon sangat menekankan nilai dari peralatan (instruments) ilmiah dalam pengumpulan data. Kedua, Aristoteles cenderung menggeneralisasikan dengan terlalu terburu-buru. ${ }^{13}$ Sebab, apabila suatu pemahaman itu kurang jelas, dan hanya merupakan hasil suatu abtraksi yang terburu-buru, tidak mungkinlah membangun sesuatu diatasnya. Dengan memberikan sedikit observasi-observasi, mereka juga menggunakan prinsip-prinsip tersebut untuk mendeduksi jangkauan (scope) yang lebih sedikit. Ketiga, Aristoteles dan pengikutnya memberlakukan deduksi dengan penghitungan yang sederhana, yang mana hubungan-hubungan dari sifatsifat tersebut ditemukan untuk mempertahankan beberapa individuindividu dari sebuah tipe yang diberikan, dinyatakan sebagai pegangan bagi keseluruhan indvidu dengan tipe tersebut. Namun, dalam praktiknya hal ini sering menghantarkan pada kesimpulan-kesimpulan yang salah, di mana hal-hal yang negatif tidak diambil sebagai catatan.

Menurut Bacon, selain dengan mudah menerima ide-ide dari yang terdahulu, para ilmuan seharusnya menyelidiki alam dengan pengamatan yang penuh kehati-hatian, dan juga menyertainya dengan percobaan-percobaan. Mereka diharapkan mampu mengumpulkan buktibukti sebanyak mungkin tentang fenomena yang sedang mereka pelajari, menggunakan eksperimen-eksperimen manakala mungkin untuk menggeneralisasikan fakta-fakta tambahan. Bagaimanapun juga, buktibukti tersebut harus dikumpulkan. Selanjutnya mereka diharuskan memegangnya dengan penuh kehati-hatian dan memberikan kesimpulankesimpulan general dari bukti-bukti tertentu.

Dinyatakan di sini eksperimen adalah sangat penting dalam proses pengambilan kesimpulan dari sebuah kesimpulan suatu teori. Kritik Bacon walau bagaimanapun bisa dibenarkan mengingat fakta yang dikumpulkan sebagai bukti untuk melakukan generalisasi adalah sangat

\author{
$12 \mathrm{Ibid}$, \\ ${ }^{13}$ C. Verhaak S.J, R. Haryono Imam, Filsafat Ilmu Pengetahuan, h.
} 142. 
penting keberadaannya, karena hal ini juga bisa meminimalisir kesalahan dari kesimpulan yang diambil setelah proses percobaan.

\section{Induktivisme-Empirisisme Francis Bacon: Suatu Tawaran bagi Metode dan Sistem Pengetahuan}

Bagi Bacon, logika silogistis-deduktif yang dikembangkan oleh Aristoteles diatas tidak sanggup menghasilkan penemuan-penemuan empiris. Bacon mengatakan bahwa silogistis-deduktif itu hanya dapat membantu mewujudkan konsekuensi deduktif dari apa yang sebenarnya telah diketahui. Agar pengetahuan itu berkembang dan demi memperoleh pengetahuan yang benar-benar berguna, konkret, dan praktis, metode deduktif harus ditinggalkan dan diganti dengan metode induktif. ${ }^{14}$ Sehingga dapat dikatakan bahwa teori induktif Bacon ini lahir sebagai jawaban atas kelemahan dari teori deduksi yang sebelumnya sering dipakai oleh Arisototeles. Harapannya adalah supaya metode induksi ini dapat menjadi metode bagi semua ilmu pengetahuan. ${ }^{15}$

Secara umum, induksi dijelaskan sebagai proses berpikir dimana orang berjalan dari yang kurang universal menuju yang lebih universal, atau secara lebih ketat lagi dari yang individual/partikular menuju ke yang umum/universal. Induksi bisa mengantarkan manusia pada tingkatan inderawi dan individual menuju ke tingkatan intelektual dan universal. ${ }^{16}$ Lebih jelasnya, penalaran induktif merupakan prosedur yang berpangkal dari peristiwa khusus sebagai hasil pengamatan empirik dan berakhir pada suatu kesimpulan atau pengetahuan baru yang bersifat umum. Karena itu, metode induksi ini tidak bisa dilepaskan dari persoalan empirisme, yaitu suatu aliran yang menjadikan pengalaman dan panca indera sebagai sumber pengetahuan. ${ }^{17}$ Untuk itu, dapat dikatakan bahwa dalam segala bentuknya yang lebih khusus, induksi merupakan persoalan generalisasi empiris, yakni kita berargumen bahwa karena sesuatu telah terbukti benar dalam sejumlah kasus yang diamati, besar kemungkinan yang diperoleh tidak bersifat pasti (kecuali dalam

\footnotetext{
${ }^{14}$ Jan Hendrik Rapar, Pengantar Filsafat, h. 113-114.

15 Loren Bagus, Kamus Filsafat (Jakarta; Gramedia Pustaka Utama,
} 1996), h. 342.

${ }^{16}$ Ibid, h. 341.

17 Manuael Velasquez, Philosophy; A Text With Readings (America: Wadsworth Publishing Company, 1999), h. 365. 
kasus-kasus khusus), tapi bisa menjadi sangat besar kemungkinannya dan seluruh prediksi rasional kita mengenai masa depan tergantung pada referensi ini. Pengambilan kesimpulan dengan induksi sudah pasti tidak sekedar masalah empiris karena kita menggunakannya untuk menyimpulkan apa yang belum kita amati.

Merujuk pada pernyataan David Hume, bahwa argumentasi yang bersifat induktif bersandar pada suatu keanekaragaman, kebiasaan dan pengalaman. Hal ini sesuai dengan apa yang menjadi stressing point Bacon dengan menekankan aspek eksperimen sebagai hal penting untuk menaklukan alam dengan rahasianya (to torture nature for her secrets). ${ }^{18}$ Dimana dalam hal ini, Bacon menyebutnya sebagai komposisi sejarah alamiah dan eksperimental (the composition of a natural anda experimental history). Menurutnya, eksperimen sangat penting karena jika kita dengan sederhana mengamati tentang apa-apa yang terjadi disekitar kita, maka kita dibatasi dalam data-data yang kita kumpulkan, ketika kita menampilkan sebuah percobaan kita mengendalikan keadaan pengamatan sejauh mungkin dan memanipulasi keadaan dari percobaan untuk melihat apa yang terjadi dalam lingkungan-lingkungan dimana hal sebaliknya tidak pernah terjadi. Eksperimen memungkinkan kita untuk menanyakan "apa yang terjadi jika ...?". Bacon menyatakan bahwa dengan mengadakan percobaan-percobaan kita mampu menaklukan alam dan rahasianya. Satu hal yang terpenting adalah bahwa 'banyak hal-hal' yang terpelihara/terjaga. Jadi, apa yang orang-orang perlu pelajari dari alam ini ialah bagaimana menggunakannya secara penuh untuk mendominasi dengan keseluruhan alam tersebut dan juga atas orang lain.

Berdasarkan pemikirannya tersebut, Bacon merumuskan dasardasar berpikir induktif modern. Hal ini karena selain mengkritik metode deduktif nya Aristoteles, Bacon juga mengkritik model induksi gaya lama. Menurutnya, metode induksi yang tepat adalah induksi yang bertitik pangkal pada pemeriksaan yang diteliti dan telaten mengenai data-data partikular, yang pada tahap selanjutnya rasio dapat bergerak maju menuju penafsiran terhadap alam (interpretatio natura). Untuk mencari dan menemukan kebenaran dengan metode induksi, Bacon mengemukakan ada dua cara yang harus dilakukan, yaitu: ${ }^{19}$

\footnotetext{
${ }^{18}$ Ibid, h. 390.

19 C. Verhaak S.J, R. Haryonono Imam, Filsafat Ilmu Pengetahuan,
} h.142. 
1. Rasio/akal budi yang digunakan harus mengacu pada pengamatan inderawi yang partikular, kemudian mengungkapnya secara umum. ${ }^{20}$ Cara ini digunakan untuk menurunkan secara deduktif ungkapan-ungkapan yang kurang umum, berdasarkan ungkapanungkapan yang paling umum. Cara ini cukup terkenal dan banyak dipakai tetapi tidak memuaskan karena data-data partikular diperiksa tidak dengan teliti, sehingga dengan bertitik tolak pada dasar yang kurang kuat akal budi meloncat pada kesimpulan dan ungkapan umum. Akibatnya dihasilkanlah anggapan yang gegabah tentang alam, yaitu generalisasi yang terburu-buru dan belum matang. Rasio/akal budi yang berpangkal pada pengamatan inderawi yang partikular digunakan untuk merumuskan ungkapan umum yang terdekat dan masih dalam jangkauan pengamatan itu sendiri, kemudian secara bertahap mengungkap yang lebih umum di luar pengamatan. ${ }^{21}$ Cara ini sebenarnya belum dijalankan, bahkan belum dicoba, namun merupakan cara yang tepat. Dengan bertitik pangkal pada pemeriksaan yang teliti dan telaten mengenai datadata partikular, akal budi maju menuju suatu penafsiran atas alam. Lebih rincinya, cara kerja metode induksi yang ditawarkan Bacon adalah sebagai berikut. Tahap pertama adalah tahap penyajian tipetipe contoh dalam alam yang diamati dan dieksperimentasi (the Presentation of Instances to the understanding). Dalam tahap ini dilakukan kompilasi data tipe-tipe contoh (instances) yang didapati dari alam ke dalam tabel-tabel. Ada tiga tabel yang harus dibuat untuk mendapatkan kepastian bentuk pengetahuan. Ketiga tabel tersebut adalah:

a. tabel 1 eksistensi dan kehadiran (Table of Existence and Presence),

b. tabel 2 tabel penyimpangan atau ketidakhadiran dalam perkiraan (Table of Deviation, or Absence in Proximity),

c. tabel 3, tabel tingkatan atau tabel perbandingan (Table of Degrees, or Table of Comparison).

2. Cara kerja tahap dua adalah: Setelah tiga langkah kompilasi data dalam tahap pertama dilakukan, cara kerja berikutnya memasuki tahap kedua dari metode Bacon, yaitu, tahap pemeriksaan atas tiga

\footnotetext{
${ }^{20}$ ibid, h.142-143.

${ }^{21}$ Ibid, h. 143.
} 
tabel dalam tahap pertama untuk menemukan apa yang disebutnya "the form" atau "bentuk" pengetahuan umum yang bisa disimpulkan dari pengamatan dan eksperimentasi atas gejala-gejala alam yang diteliti.

Selanjutnya, untuk menghindari penggunaan metode induksi yang keliru, Bacon menyarankan agar menghindari empat macam "idols" atau rintangan dalam berpikir, yaitu: ${ }^{22}$

1) Idols of the tribes yaitu kekeliruan-kekeliruan yang disebabkan oleh kecenderungan yang melekat dalam sifat manusia. Hal ini terbukti ketika manusia yang cenderung mengukur dari sudut pandangnya sendiri, tidak mendasarkan pandangannya pada realitas yang dilihatnya. Akibatnya, manusia mengabaikan objek yang dilihatnya karena manusia menerapkan ukuran yang sebenarnya tidak ada pada sesuatu itu.

2) Idols of the cave, maksudnya adalah kekeliruan-kekeliruan yang disebabkan subjektivitas manusia yang cenderung prejudice (berprasangka), terlalu yakin pada anggapannya sendiri yang dipengaruhi oleh watak, pendidikan, pembacaan, dan pengaruhpengaruh khusus yang tertanam dalam diri manusia.

3) Idols of the market-place adalah kekeliruan-kekeliruan yang disebabkan manusia terlalu percaya pada bahasa atau kekuatan katakata. Idols of the market-place ini adalah Idols yang paling berbahaya. Acuannya adalah pendapat orang yang diterimanya begitu saja sehingga mengarahkan keyakinan dan penilaiannya yang tidak teruji.

4) Idols of the theatre. Adalah sistem-sistem filsafat atau pengetahuan masa lampau yang keliru dalam memersepsi realitas. Idols ini menunjukkan bahwa manusia cenderung mempercayai pada pengetahuan yang bersumber pada tradisi atau budaya yang telah diwariskan secara turun temurun tanpa pikiran yang kritis. disinilah Bacon menegaskan bahwa ilmuwan sejati adalah pengamat yang objektif yang dapat membebaskan manusia dari ilusi dan mitos di masa lalu. Bacon juga mengibaratkan ilmuan itu haruslah seperti lebah, yang mengumpulkan materi dari bunga-bunga di kebun dan taman, lalu mengolahnya dan mentransformasikannya dengan

22 Ali Maksum, Pengantar Filsafat, 121-122. Lihat juga C. Verhaak S.J, R. Haryonono Imam, Filsafat Ilmu Pengetahuan, h. 143. 
kekuatannya sendiri. Tidak separti laba-laba yang merajut jaring dari fantasinya sendiri, ataupun tidak seperti semut yang bisanya hanya mengumpulkan. ${ }^{23}$ Pengibaratan laba-laba ini oleh Bacon dikatakan seperti cara kerja metode silogistis-deduktif. Sedangkan semut, diibaratkannya seperti metode induktif yang lama (tradisional). ${ }^{24}$

Ciri khas induksi adalah ia mampu menemukan dasar Inti (formae) yang melampaui data-data partikular, betapapun besar jumlahnya. Sehingga yang perlu dilakukan di sini adalah mengumpulkan data-data heterogen tentang suatu hal. Dari sini kemudian akan tampak dengan jelas peristiwa konkret partikular yang sebenarnya terjadi (latens processus dengan sebab efisiennya), dan dilanjutkan dengan hal-hal yang lebih umum sifatnya (latens schematismus dengan sebab meterialnya), baru kemudian ditemukan dasar intiya. ${ }^{25}$ Maka, inti dari induksi gaya Bacon ini adalah bahwa ilmu pengetahuan harus bermula dari dan dikendalikan oleh pengamatan yang tidak terpengaruh oleh pengandaian apapun juga. Ilmuan harus mendekati alam atau objek penelitiannya dengan menggunakan mata yang lugu, dan tidak dicemari oleh anggapan apapun juga. Ia tidak beleh dikuasai oleh praduga-praduga apa pun. Jadi, ia harus membiarkan objek berbicara kepadanya tanpa berusaha agar objek itu harus cocok dengan kerangka atau dugaan yang sudah ada dalam benaknya. ${ }^{26}$

Karena itu, ada tiga hal pokok yang ingin disampaikan Bacon melalui metode induktif-empiris ini. Pertama, ketika mengadakan penelitian ilmiah, ilmuan harus bebas dari segala pengandaian. Kita harus bebas dari segala macam spekulasi awal, yang dapat memperdaya kita dalam mengamati objek penelitian kita. Kasarnya, segala macam teori, segala macam anggapan, dugaan, dan pikiran tentang objek penelitian harus dibuang jauh-jauh untuk bisa memungkinkan kita menangkap objek sebagaimana adanya. Tujuannya adalah untuk mencegah bias ilmiah. Bias ilmiah bisa terjadi ketika ilmuwan hanya menggunakan data adan fakta sekedar untuk membenarkan pemikiran

${ }^{23}$ Ali Maksum, Pengantar Filsafat, h.122.

${ }^{24}$ Jan Hendrik Rapar, Pengantar Filsafat, h.114.

${ }^{25}$ C. Verhaak S.J, R. Haryonono Imam, Filsafat Ilmu Pengetahuan, h. 143-144.

26 A. Sonny Keraf, Mikhael Dua, Ilmu Pengetahuan; Sebuah Tinjauan Filosofis, h. 100-101. 
atau teori yang sudah dimilikinya. Akibatnya, ada kecenderungan untuk hanya memperhatikan data yang relevan dengan kerangka pemikiran yang sudah ada, dan sebaliknya tidak menghiraukan fakta dan data yang bertentangan dengan kerangka pemikiran yang ada. Sehingga, kesimpulan yang diperoleh memang sah, tetapi meleset atau keliru. Kedua, sebisa mungkin memperhatikan data dan fakta yang bertentangan satu sama lain. Dan ketiga, setelah mengamati objek sebagaimana adanya, dan mengumpulkan data dan fakta tentang objek itu, data dan fakta tersebut hendaklah dievaluasi, diklasifikasi, dirumuskan, dan di simpulkan sesuai dengan kemampuan yang dimiliki oleh ilmuan itu. Jadi, baru pada tingkat inilah ilmuan dapat menggunakan berbagai macam konsep dan teori yang telah diketahui untuk mengolag data yang ada. Pada tingkatan inilah akal budi dan pengamatan inderawi saling menunjang untuk memperoleh kesimpulan yang dapat diandalkan. ${ }^{27}$

\section{E. Konstruksi Induktivisme-Empirisisme Francis Bacon}

Untuk mengetahui bangunan dan susunan apa saja yang digunakan Bacon dalam menghimpun metode induksi-empiris, disini akan penulis bagi menjadi empat poin. Yaitu:

1. Sumber dan Hakikat Pengetahuan

Terkait dengan sumber dan hakikat pengetahuan dalam perspektif epistomologi Bacon, kita bisa mengabstraksikan metode Bacon secara simple dan sampai pada sebuah catatan sederhana tentang metode ilmiah. Pada intinya, induktivisme Bacon berakar pada dua pilar; Observation dan induction. Observasi yang dilakukan dalam memperoleh knowledge harus diambil tanpa praduga (prejudice) atau pre-konsepsi (preconception). Ini menegaskan pemikiran Bacon yang menisbikan pengetahuan akal yang telah ada - anggapan tanpa rasionalitas - dan bahwa kita juga diwajibkan untuk mencatat atau merekam hasil-hasil dari data-data pengalaman sensorik. Hasil-hasil dari pengamatan diungkapkan dalam sesuatu yang dinamakan pernyataan observasi (observation statments). Dari sebuah kesimpulan pengamatan tersebut bisa digunakan sebagai landasan bagi hukum-hukum dan teoriteori ilmiah. Selanjutnya, proses induksi yang akan dilakukan untuk memahami pendekatan Induktif Bacon ini adalah dengan memulainya dari bagian-bagian yang bisa diamati dan kemudian dipikirkan ke dalam

${ }^{27}$ Ibid, h. 101. 
pernyataan-pernyataan umum ataupun hukum-hukum. Karena itulah fenomena-fenomena alam sangat mendukung sebagai salah satu sumber pengetahuan, di mana hakikat pengetahuannya adalah mengetahui alam dari alam, a posteriori.

\section{Alat Pengetahuan}

Dengan menggunakan empirisme, maka dapat diketahui bahwa apa yang menjadi tools oleh Bacon dalam menyusun ataupun memperoleh pengetahuan adalah dengan mengfungsikan sarana panca indera manusia. Meskipun Bacon adalah seorang empirisme, namun dalam hal ini dia tidak pernah menafikan peran akal Pengalaman melalui penglihatan, penciuman, dan merasakan bisa mampu menghantarkan manusia pada sebuah proses pencapaian pengetahuan.

Karena itu, indera: sensation (observable and measurable) menjadi Instrumen dominan Pengetahuan yang digunakan untuk menangkap fenomena-fenomena realitas yang selanjutnya diobservasi secara terus menerus dan berkelanjutan. Selanjutnya data ini dipersepsikan oleh akal melalui sebuah kesimpulan yang terikat pada fenomena pengamatan. Pada tahapan akhir, Bacon menciptakan sebuah teori epistomologi induktivisme sebagai kesimpulan dari observasi tersebut. Teori Induksi ini, dalam pengertian luas adalah suatu bentuk pemikiran di mana kita menggeneralisasikan dari sebuah keseluruhan pengamatan terhadap kumpulan bagian-bagian penting untuk sebuah kesimpulan umum. Karena induksi sendiri memiliki beberapa sifat yang tidak boleh dihilangkan atau diabaikan.

Diantara sifat-sifat yang tidak boleh diabaikan tersebut adalah: ${ }^{28}$

a. Bukan subjektivitas, sampai menjadi tergantung dari perasaan dan keinginan pribadi, melainkan mengenal objek dalam dirinya sendiri.

b. Bukan pragmatis, sampai mencari untung atau kegunaan praktis tetapi melihat objek apa adanya.

c. Bukan abstrak, sampai terjadi hal konkret dan individual tidak digubris lagi, tetapi justru situasi dan lingkungan konkret dipahami.

28 Anton Bakker dan Achmad Charis Zubari, Metodologi Penelitian Filsafat, (Yogyakarta: Kanisisus, 1990), h. 43-44. 


\section{Teori Kebenaran Pengetahuan}

Metode/cara untuk memperoleh pengetahuan adalah Eliminative Induction, yang meliputi:

a. Observasi-eksperimentasi atas fakta-fakta alam;

b. Didata dalam tabel positif dan negative;

c. Kemudian generalisasi untuk penetapan teori pengetahuan (setelah tidak ditemukan fakta negatif)

Jika diuraikan lewat contoh, metode induktif yang dikembangkan oleh Bacon adalah sebagai berikut:

"Bacon ingin mengetahui tentang sifat panas yang diduganya merupakan gerakan-gerakan tidak teratur yang cepat dari bagianbagian kecil dari suatu benda. Ia lalu membuat daftar dari bendabenda yang memiliki tingkatan panas yang berbeda. Lewat penelitian dan penyelidikan yang seksama terhadap daftar dari masing-masing kelompok benda itu, ia berupaya menemukan karakteristik yang senantiasa hadir pada benda-benda panas, karakteristik yang tidak terdapat pada benda-benda dingin, dan yang selalu ada pada benda-benda yang memiliki tingkatan panas yang berbeda. Dengan demikian, ia berhrap akan berhasil menemukan suatu hukum yang berlaku umum tentang apa yang diselidikinya itu. ${ }^{29}$

Masih dalam rangka menemukan hakekat panas mulai dari panas yang diperoleh dari tangan yang digosok-gosok, hingga panas yang diperoleh dengan panas matahari, Bacon berpendapat bahwa panas itu sebenarnya adalah gerak yang terjadi pada partikel yang lebih kecil dari suatu benda yang pada ahirnya menghasilkan panas pada benda apa pun. ${ }^{30}$

Sekurangnya, ada dua manfaat dari metode induksi gaya Bacon ini. Pertama, dengan metode ini ilmuwan benar-benar melihat kenyataan secara objektif, dan bukan kenyataan sebagaimana dilihat dari kaca mata ilmuawan. Selain itu, dalam hal ini kenyataan tidak dipaksakan untuk cocok dengan apa yang telah dipikirkan oleh ilmuwan. Sehingga dapat dikatakan bahwa metode induksi gaya Bacon ini berguna untuk memungkinkan ilmuwan sampai pada kebenaran yang objektif. Oleh

${ }^{29}$ Jan Hendrik Rapar, Pengantar Filsafat, h. 114-115.

${ }^{30}$ Ali Maksum, Pengantar Filsafat, h.122. 
karena itu, kesimpulannya pun benar-benar mengungkapkan kenyataan sebagaimana adanya. ${ }^{31}$

Kedua, dalam kaitannya dengan itu, kegiatan ilmiah tidak jatuh menjadi ideologi. Pola pikir dan cara kerja ideologi selalu cenderung membenarkan ideologi yang ada, yaitu rumusan-rumusan baku yang dianggap benar dengan sendirinya, dan yang karena itu semua macam hal dipaksakan untuk membenarkan "keluhuran" ideologi itu. Padahal, ilmu justru sebaliknya berupaya membongkar segala urusan baku untuk bisa sampai pada kebenaran sejati. Hal ini berarti bahwa, kegiatan ilmiah itu buakan lagi bertujuan mencari fakta dan data yang membenarka ide, konsep, atau teori yang sudah ada, tetapi mengungkap kenyataan sebagaimana adanya, termasuk kenyataan yang tidak sesuai dengan apa yang telah dipikirkan. ${ }^{32}$

Dengan kata lain, di sini Bacon mengusulkan sebuah metode yang dengan metode itu ilmuwan dapat menghasilkan teori yang memiliki kemungkinan kebenaran yang lebih tinggi derajatnya dibanding dengan metode yang lain. Karena sejarah pun telah membuktikan bahwa ilmu pengetahuan medern, khususnya empiris, telah berkembang sangat pesat justru atas jasa induksi gaya Bacon ini.

4. Pengujian Kebenaran Pengetahuan

Setiap teori, pastinya tidak pernah lepas dari kurangan. Begitupun dengan metode induksi gaya Bacon. Setidaknya ada dua keberatan atas induksi gaya Bacon ini dan cara kerja induksi pada umumnya. Pertama, betapun menariknya metode yang ditawarkan Bacon, dalam kenyataannya kita tidak pernah mendekati, meneliti, dan membaca alam dengan mata telanjang yang kosong sama sekali. Kita tidak bisa melakukan pengamatan apapun atas alam tanpa ide tertentu tentang alam yang sedang kita amati. Karena semua pengamatan kita mau tidak mau sudah dipengaruhi oleh pengertian tertentu tentang apa yang sedang kita amati. Jadi intinya, kita tidak bisa mengamati alam dengan akal budi yang kosong sama sekali. ${ }^{33}$ Sebab, disadari atau tidak, ketika kita mengamati suatu objek, kita sesungguhnya telah memiliki

${ }^{31}$ A. Sonny Keraf, Mikhael Dua, Ilmu Pengetahuan; Sebuah Tinjauan Filosofis, h.102.

${ }^{32} \mathrm{Ibid}$.

33 A. Sonny Keraf, Mikhael Dua, Ilmu Pengetahuan; Sebuah Tinjauan Filosofis, h.102. 
kerangka teoritis dan asumsi tertentu. Bahkan kita sudah mempunyai hipotesis tertentu sebagai hasil dari abduksi. ${ }^{34}$ Abduksi adalah proses yang terjadi dalam pemikiran ilmuan untuk mencari dan merumuskan hipotesis. Galileo bahkah mengatakan bahwa indera itu menipu, dia mengatakan "saya tidak dapat mengungguli kecerdasan manusia, bahwa yang ia terima dan ia pertahankan adlah benar. Dan dengan pendapat yang mereka ajukan, hal itu berarti memperkosa indera mereka sendiri; kerena dengan demikia mereka telah menetapkan bahwa akal budi mereka telah didekte sehingga eksperimen yang masuk akal menunjukkan dengan sangat jelas hal-hal yang bertentangan. Sebagai cotoh, kita tampaknya melihat matahari bergerak melintasi langit, sesungguhnya matahari tidak bergerak melintasi langit. Akal budi menunjukkan bahwa bumilah yang bergerak dan matahri diam. Akal budi melakukan pemaksaan terhadap indera sehingga ia mengatakan tentang "pemerkosaan akal budi atas indera". Tetapi kita harus mempercayai akal budi, bukan indera. Karena indera dapat menipu kita, tetapi akal budi memberitahukan kebenaran kepada kita." 35

Sebagai contoh, ketika kita ingin meneliti tentang batu, setidaknya kita sudah punya gambaran umum dan konsep tertentu tentang batu, sehingga kita bisa memastikan bahwa itu adalah batu, bukan kayu, dari sinilah kita bisa membuat klasifikasi tertentu mengenai hal yang sedang kita amati tersebut.

Namun, yang harus ditekankan di sini adalah bahwa Bacon hanya menginginkan supaya kita jangan sampai terbelenggu oleh asumsi-asumsi teoritis tertentu yang cenderung memaksakan fakta dan data untuk sesuai dengan asumsi kita. Untuk itu, yang perlu diingat adalah bahwa pengandaian, konsep, dan asumsi teoritis itu harus tetap terbuka untuk diubah berdasarkan fakta dan data yang kita temukan sebagaimana adanya. Bahkan kalau perlu malah ditinggalkan jika memang tidak lagi sesuai dengan fakta dan data yang ada di lapangan. ${ }^{36}$ Dalam hal ini asumsi teorotis memang diperlukan sebagai alat bantu untuk melahirkan hukum atau teori baru, dan bukan sasaran yang harus dicapai.

${ }^{34}$ Ibid, h. 92.

${ }^{35}$ Hector Hawton, Filsafat yang Menghibur; Penjelajahan Memasuki Ide-ide, terj. Supriyanto Abdullah (Yogyakarta: Ikon Teralitera,2003), h.37-38.

${ }^{36} \mathrm{Ibid}$, h. 103. 
Kedua, bahwa fakta, data, dan fenomena, tidak pernah menampilkan dirinya kepada kita sebagi fakta, data, atau fenomena yang telanjang begitu saja. Karena dalam hal ini fakta tersebut perlu ditafsirkan. Oleh karena itu, Bacon keliru kalau dia menyingkirkan begitu saja spekulasi ilmiah. Padahal untuk melakukan penafsiran tersebut, seorang ilmuan harus mempunyai konsep, spekulasi, atau imajinasi tertentu dan aktif berpikir tentang objek tersebut. ${ }^{37}$

Dengan begitu, dapat dikatakan bahwa sikap dasar empirisme yang mengandalkan metode induksi untuk memperoleh fakta melalui pengamatan indrawi sebagai dasar pengetahuan ilmiah kiranya berlebihan. Sehingga tidak dapat dipungkiri lagi bahwa akal budi pun turut berperan aktif dalam mengungkap suatu makna. Karena kalau tidak, maka tidak akan ada yang namanya penemuan ilmiah (scientific discovery), sebab tidak semua orang bisa tahu dengan sendirinya bahwa fakta tertentu mengungkapkan hukum atau teori tertentu. Meski demikian, bukan berarti induksi ini tidak dapat digunakan. Sebab, dalam bidang agama, ada beberapa persoalan yang memang harus diselesaikan dengan menggunkan metode induksi ini, sebagaimana yang akan dijelaskan di bawah ini.

\section{F. Relevansi Induktivisme-Empirisisme Francis Bacon bagi Ilmu- ilmu Keagamaan}

Mengembangkan sebuah teori filsafat dalam Ilmu-ilmu Keagamaan tidaklah mudah. Walaupun demikian, itu tetap harus dilakukan jika seseorang ingin menjadi orang yang handal dan bijaksana dalam setiap keputusan yang akan diambilnya. Pembacaan InduktivismeEmpirisisme Francis Bacon ternyata mampu membawa implikasi yang positif bagi Ilmu-ilmu Keagamaan. Dengan penarikan persepsi dari khusus ke umum yang dipadu dengan pengamatan inderawi yang benarbenar jujur dapat menghasilkan kesimpulan yang tidak idialisme dan merasa benar sendiri.

Didalam kajian Islam, induksi dikenal dengan istilah istiqra'. Dalam bidang fiqh, metode induksi ini dapat dijumpai di sistem ijma' yang biasa digunakan oleh fuqoha dalam mengambil sebuah keputusan hukum. Berangkat dari kasus-kasus hukum spesifik dalam figh, dan dengan meneliti ayat-ayat al-Qur'an serta al-hadis Nabi, seorang fuqoha

${ }^{37}$ Ibid, h. 104. 
bisa sampai pada prinsip umum hukum Islam. prinsip umum ini dibentuk secara induktif (istiqra') dari berbagai kasus hukum yang spesifik. Kandungan utama dari prinsip-prinsip ini adalah hikmah hukum, yang pada gilirannya akan menjadi jalan terbentuknya kajian tentang apa yang disebut dengan istilah al-qawa'id al-fiqhiyah (kaidah-kaidah fiqh). Materi-materi ijma' juga didapatkan melalui penelitian lapangan. Sebagai contoh, dalam menetapkan pentingnya niat dalam setiap perbuatan, para fuqoha kemudian mengumpulkan dalil-dalil dari berbagai sumber. Artinya, apa yang mereka lakukan ini berangkat dari keadaan yang khusus lalu disimpulkan kepada sesuatu yang umum. Meskipun induksi adalah dasar hukum yang diperselisihkan oleh sebagian ulama, akan tetapi metode ini diterima validitasnya. Bahkan wajib diamalkan berdasarkan hadis Nabi yang semakna dengan yang telah disebut, "نحن نحكم بـالظواهر" (kami memutuskan berdasarkan apa yang tampak).

Selain itu, metode yang ditawarkan Bacon ini juga dapat diaplikasikan dalam kajian yang dikenal dengan istilah "living Qur'an dan living hadis", yaitu sebuah kajian tentang "berbagai peristiwa sosial terkait dengan kehadiran atau keberadaan al-Qur'an dan hadis di sebuah komunitas Muslim tertentu." 38 Dengan pengertian seperti ini, maka "dalam bentuknya yang paling sederhana" The Living Qur'an tersebut "pada dasarnya sudah sama tuanya dengan Qur'an itu sendiri. Penelitian terhadap pemahaman al-Qur'an dan hadis-hadis yang dipraktekkan oleh masyarakat tertentu ini sangat terkait erat dengan aspek sosiologi dan antropologi. Ini karena kajian-kajian berangkat dari pengamatan terhadap suatu masalah praktik-praktik keagamaan seperti tahlilan dan yasinan yang dilakukan oleh umat Islam yang ternyata jika ditelah lebih seksama, praktik-praktik keagamaan tersebut sebenarnya terkandung di dalam alQur'an ataupun hadis Nabi. Sehingga, kita pun tidak buru-buru menganggap praktik tersebut bid'ah atau bahkan sesat. Inilah yang sejatinya dikehendaki Bacon dengan metode induksi empirisnya, bahwa ilmu pengetahuan itu harus bersifat objektif sehingga menghasilkan kesimpulan yang bijak seperti tujuan dari filsafat itu sendiri.

${ }^{38}$ M. Mansyur, "Living Qur'an dalam Lintasan Sejarah Studi Qur'an," dalam Sahiron Syamsuddin (ed), Metodologi Penelitian Living Qur'an dan Hadis, (Yogyakarta: Teras,2007), h. 8-9. 


\section{F. Kesimpulan}

Induktivisme-Empirisisme Francis Bacon ternyata telah mampu menjawab keterbatasan metode berpikir deduksi Aristoteles. Kritikkritiknya mampu menyajikan berbagai pengetahuan baru dalam ilmu pengetahuan, khususnya dengan penilaiannya yang objektif. Karena dengan penilaian yang objektif, ilmu lebih leluasa menampakkan dirinya. Namun, terlepas dari segala kelebihan yang dimiliki, ternyata induktivisme Bacon juga memiliki beberapa kelemahan, hal ini tidak lepas dari sifat kebenaran ilmu pengetahuan yang tidak bisa dicapai dengan mutlak. Sifat ilmu pengetahuan hanya mampu mengantarkan the thinkers mendekati kepada kebenaran itu sendiri. Dalam pengertian penulis di sini, bahwa tidak semua yang kita percaya dalam sebuah keyakinan harus dipercaya juga oleh orang lain. Praktisnya, kita senantiasa diharapkan untuk saling menghargai view ilmu pengetahuan dengan tanpa mengabaikan landasan kritis. Dengan demikian akan tercipta dinamika keilmuan yang harmonis dan dinamis. Ini karena sikap tertutup hanya akan membentuk manusia gua sepanjang waktu, maka dari itu perlu kita membuka wilayah ilmu pengetahuan dengan tetap menjaga nilai-nilai harmonis. Induktivitas bukan hanya satu-satunya metode reasoning yang bisa dibenarkan. Bagaimanapun ia tetap memiliki kelemahan-kelemahan yang bisa ditutupi dengan metode berpikir lainnya. Pada akhirnya, adalah sebuah tuntutan bagi kita untuk bisa mensinergikan semuanya dalam segala ranah ilmu pengetahuan; agama, sosial, pendidikan dan lain sebagainya. Sebab, sebagaimana yang telah dibahas di atas, metode yang ditawarkan oleh Bacon ini mampu membedah dan menyelesaikan permasalah-permasalah keagamaan yang berkembang dikehidupan umat Islam dari sejak dulu hingga sekarang.

\section{Daftar Rujukan}

Bagus, Loren. Kamus Filsafat, Jakarta; Gramedia Pustaka Utama, 1996.

Dua, Mikhael. A. Sonny Keraf. Ilmu Pengetahuan; Sebuah Tinjauan Filosofis, Yogyakarta: Kanisius, 2001.

Haryonono, Imam. C. Verhaak S.J, R. Filsafat Ilmu Pengetahuan (Jakarta: Gramedia: Pustaka Utama, 1991. 
Hawton, Hector. Filsafat yang Menghibur; Penjelajahan Memasuki Ideide, terj. Supriyanto Abdullah, Yogyakarta: Ikon Teralitera,2003.

Kattsoff, Louis O. Pengantar Filsafat, terj. Soejono Soemargono, Yogyakarta: Tiara Wacana, 2004.

Maksum, Ali, Pengantar Filsafat, Yogyakarta: ar-Ruzz Media, 2011.

Syamsuddin, Sahiron (ed), Metodologi Penelitian Living Qur'an dan Hadis, Yogyakarta: Teras, 2007.

Rapar, Jan Hendrik, Pengantar Filsafat, Yogyakarta: KANISIUS, 1996.

Velasquez, Manuael. Philosophy; A Text With Readings, America: Wadsworth Publishing Company, 1999.

Zubaedi, dkk. Filsafat Barat; Dari Logika Baru Rene Descartes Hingga Revolusi Sains ala Thomas Kuhn, Yogyakarta: ar-Ruzz Media, 2007.

Zubari, Achmad Charis. Anton Bakker. Metodologi Penelitian Filsafat, Yogyakarta: Kanisisus, 1990. 
Yeni Setianingsih

Halaman ini tidak dengan sengaja dikosongkan 